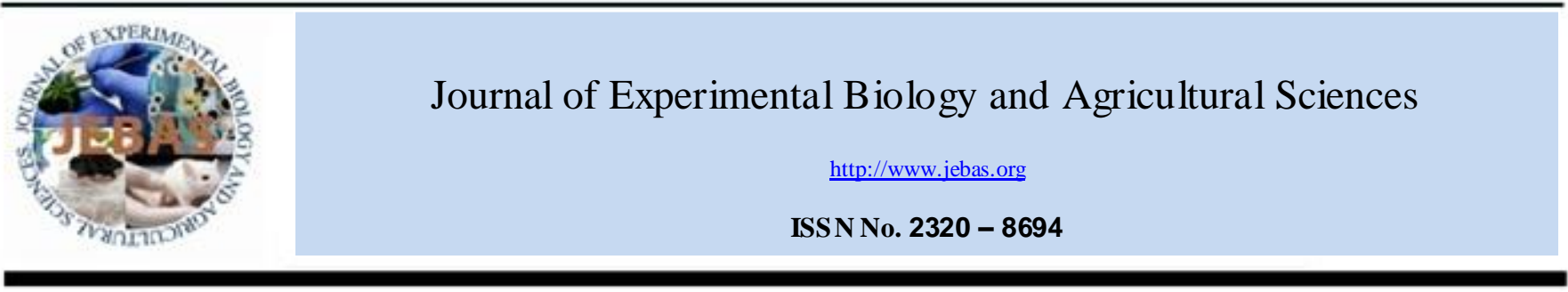

\title{
FIBER AND SUGAR CONTENTS IN VEGETABLES PRESCRIBED AND CONSUMED BY DIABETICS IN KISANGANI
}

\section{Lusamaki Mukunda $^{1, *}$, Solomo Elumbu ${ }^{2}$, Kayisu Kalenga ${ }^{3}$, Nyongombe Utshudienyema ${ }^{4}$, Posho Ikolonga $^{5}$, Mbutu Mango ${ }^{6}$, Losimba Likwela ${ }^{7}$ and Batina Agasa $^{8}$}

\footnotetext{
${ }^{1}$ Department of Human Nutrition, Faculty of Medicine and Pharmacy, University of Kisangani

${ }^{2}$ Faculty of Science, University of Kisangani

${ }^{3}$ Department of Chemistry and Agricultural Industries Faculty Institute of Agricultural Sciences of Yang ambi

${ }^{4}$ National Pedagogical University

${ }^{5}$ Department of Public Health, Faculty of Medicine and Pharmacy, University of Kisang ani

${ }^{6}$ High institute of Medical Techniques of Kisangani

${ }^{7}$ Department of Public Health, Faculty of Medicine and Pharmacy, University of Kisang ani

${ }^{8}$ University Clinics, Faculty of Medicine and Pharmacy, University of Kisangani
}

Received - January 17, 2015; Revision - March 05, 2015; Accepted - June 11, 2015

Available Online - June 19, 2015

DOI: http://dx.doi.org/10.18006/2015.3(3).275.280

\section{KEYWORDS \\ Diabetic \\ Vegetable consumption \\ Dietary fiber \\ Sugars}

* Corresponding author

E-mail: f.lusmuk@yahoo.fr (Lusamaki Mukunda)

Peer review under responsibility of Journal of Experimental Biology and Agricultural Sciences.

Production and Hosting by Horizon Publisher (www.my-

vision.webs.com/horizon.html)

All rights reserved.

\begin{abstract}
ABSTRAC T
Consumption of high fiber foods such as fruits and vegetables is beneficial in stabilizing blood sugar. Therefore present study has been conducted to evaluate and determine the fiber and total sugar contents in leafy vegetables prescribed to diabetics in Kisangani. Fifty Nine participants (aged between 30 to 79 years) suffering from diabetes mellitus were interviewed on consumption of leafy vegetables that health workers prescribe for them. Result of the study revealed that $41.1 \%$ of the respondents consumed vegetables at least once in a day while $30.5 \%$ respondents consumed vegetables twice in a day. The most consumed vegetables were Manihot esculenta (84.8\%), Amaranthus hybridis (55.9\%) and Ipomoea batatas $(41.1 \%)$. The fiber content ranges from $1 \mathrm{~g} / 100 \mathrm{~g}$ (Bracica oleracea \& Solanum nigrum) to $3.6 \mathrm{~g}$ $/ 100 \mathrm{~g}$ (Amaranthus hybridis) while the sugar content was reported from $2.5 \mathrm{~g} / 100 \mathrm{~g}$ ( Abelmoschus esculentus) to $15.5 \mathrm{~g} / 100 \mathrm{~g}$ (Manihot esculenta). Results of the study identified some leafy vegetables which are rich in dietary fiber and consumption of these would be beneficial for the diabetics.
\end{abstract}

All the article published by Journal of Experimental Biology and Agricultural Sciences is licensed under a Creative Commons Attribution-NonCommercial $\quad 4.0$ International License Based on a work at www.jebas.org.

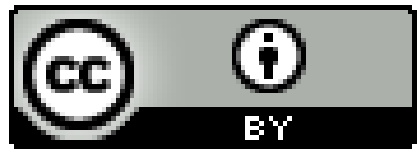




\section{Introduction}

Diabetes mellitus is a result of chronic insulin resistance and loss of pancreatic beta cells. Strategies to retain these cells are required in the prevention and treatment of this devastating disease (Gilbert \& Liu, 2013). Prevalence of type 2 diabetes has increased all over the world (Kobayashi et al., 2013) and is considered as a growing threat to global health it is the most current endocrine disease (Tol et al., 2013). Dietary factor plays an important role in controlling blood sugar in diabetics (Gurukar et al., 2013). Thus, having a healthy diet basically a considerable intake of dietary fiber, antioxidants, including carotenoids, vitamins A, C, E, minerals such as selenium and phytochemical compounds would be a better source to overcome this disease. Ve getables and fruits are considered the main sources of these substances (Kaczmarczyk et al., 2012; Tabesh et al., 2013; Boeing et al., 2012; Isao et al., 2013). Dietary fibers of these suggested vegetables and fruits stimulate the secretion of glucagon like peptide-1 (GLP-1) hormone, this hormone is responsible for increasing the secretion of insulin and prevents the destruction of beta cells in the pancreas (Ramon, 2009). Similarly Gilbert \& Liu (2013) reported the presence of a flavonoid Genistein from soy; this flavonoid has similar effects in reducing the effect of diabetic. Antioxidant nutrients can reduce chronic disorders and diabetes complications by inhibiting the oxidation reactions of organic molecules (Savini et al., 2013).

In the Democratic Republic of Congo (DRC), the consumption of vegetables is influenced by dietary habits and culture. Kisangani has some native vegetables whose consumption wo uld be more beneficial for diabetics but their fiber and sugar contents are poorly documented. The aim of this study is to assess the consumption frequency of vegetables prescribed to diabetics by the health care workers and to determine the fiber and sugar content of some of these vegetables.

\section{Materials and Me thods}

\subsection{Study area}

Study was conducted in the general reference hospital MakisoKisangani (HGR / Makiso-Kisangani), general reference hospital Kabondo (HGR/Kabondo), University Clinics of Kisangani (CUKIS) and two associations of diabetics of Kisangani. The determination of fiber and sugar contents in vegetables was carried out in chemistry laboratory of the faculty of Science of the University of Kisangani (UNIKIS).

\subsection{Respondents}

This cross-sectional study was conducted from March 24 to June 29, 2014, in diabetic patients who consulted the above health facilities and those who participated in nutrition education sessions in their associations. The selection of patients was done only occasionally. All patients who had been included in this study were consulted by a caregiver and had received advice on leaf vegetable consumption and agreed to answer the questions of surveyors. Amongst the selected 63 respondents 59 respondents were agreed on the basis of said criteria while the rest four were not agreed. Amongst the selected fifty nine respondents 33 were found in the associations of diabetics, 11 in HGR / Kabondo, 10 in HGR / Makiso- Kisangani and 5 in CUKIS. All the required data were extracted by interview technique supported by a survey. The investigated variables were age, sex, health personnel consulted, the consumption of prescribed vegetables. Data were analyzed for percentage and the arithmetic mean. The chi-square test for single sample was used to compare different means observed on prescribed, non prescribed, consumed and non consumed vegetables for significance level of 0.05 using SP SS 20 software

\subsection{Prescribed Vegetables}

Information regarding all the prescribed vegetables was collected from various sources and total eleven vegetables viz Spinaccia oleracea (spinach), Cucurbita pepo (pumpkin sheet) Bracica oleracea (cabbage), Solanum nigrum (black nightshade), Ipomoea batatas (sweet potato leaf) Abelmoschus esculentus (dongo dongo) Hibiscus acetosella (Sorrel of Guinea), Colocasia esculenta (Taro leaf) Manihot esculenta (cassava leaf) Amaranthus hybridis (amaranth), Gnetum africanum (fumbwa) were cited and all were analyzed for fiber and sugar content.

Fresh vegetables were purchased from the central market of Kisangani and immediately brought to the laboratory for further analysis. Hundred grams fresh sample from edible portion of the each vegetable has been collected and dried in an oven at $37^{\circ} \mathrm{C}$. After drying, the sample was converted into powder using a mortar. This powder was used for the determination of fiber and sugars.

Total fiber content was determined by the method describe $\mathrm{d}$ by Association of Official Analytical Chemists (AOAC, 1990). Indeed, Five grams of dry matter were introduced into a cartridge of the soxhlet extractor adapted to a tarred flask containing $250 \mathrm{ml}$ of petroleum ether. The flask was heated until the complete clarification of the solvent. After the extraction the content of the cartridge was recovered and placed in an Erlen Meyer flask containing $200 \mathrm{ml}$ of $1.25 \%$ sulf uric acid. The content of flask was boiled for 30 minutes, cooled and filtered through a filter paper and then washed three times with $50 \mathrm{ml}$ of hot water. The residue is returned into the Erlen Meyer flask while adding $200 \mathrm{ml}$ of $1.25 \% \mathrm{NaOH}$ and heated for 30 minutes. It is then cooled, filtered again and washed three times with $50 \mathrm{ml}$ of hot water and finally with $25 \mathrm{ml}$ of ethanol. The residue was then dried at $130^{\circ} \mathrm{C}$ in an oven to constant weight, cooled in a desiccator and transferred to oven dried previously weighted porcelain crucible. The crucible is then heated for 2 hours in an oven at $550^{\circ} \mathrm{C}$ then cooled and weighed. The percent fiber is equal to the difference between the weight of the cake after the extraction 
of lipid and the weight of the sample after calcinations divided by the weight of the sample before the extraction of lipid multiplied by one hundred.

The determination of sugars was made according to the method described by Dubois et al. (1956). To $0.5 \mathrm{~g}$ sample powder is added $10 \mathrm{ml}$ of $1.5 \mathrm{~N} \mathrm{H}_{2} \mathrm{SO}_{4}$ and mixed properly. This mixture was boiled at $100^{\circ} \mathrm{C}$ in a water bath for 15 minutes, and cooled it at room temperature. $10 \mathrm{ml}$ of $70 \%$ ethanol, 0.5 $\mathrm{ml}$ of $\mathrm{ZnSO}_{4}$ and $0.5 \mathrm{ml}$ of potassium ferrocyanide were added in this cooled mixture. The suspension was filtered on Whatman paper and the filtrate was collected in a $50 \mathrm{ml}$ flask and brought to the volume with distilled water. $0.5 \mathrm{ml}$ of the filtrate was taken in flask and $1.5 \mathrm{ml} \mathrm{ml}$ of distilled water, $1 \mathrm{ml}$ of aqueous phenol and then $5 \mathrm{ml}$ of concentrated $\mathrm{H}_{2} \mathrm{SO}_{4}$ were added in this mixture; keep it for 10 minutes and optical densities were taken at $490 \mathrm{~nm}$. For the blanc, to $2 \mathrm{ml}$ of distilled water were added $1 \mathrm{ml}$ of aqueous phenol and $5 \mathrm{ml}$ of concentrated $\mathrm{H}_{2} \mathrm{SO}_{4}$.

A standard solution of glucose $(0.5 \mathrm{mg} / \mathrm{ml})$ was prepared from which were prepared the 5 solutions of various concentrations viz $0 \mathrm{mg} / \mathrm{ml}, 0.025 \mathrm{mg} / \mathrm{ml} ; 0.050 \mathrm{mg} / \mathrm{ml} ; 0.075 \mathrm{mg} / \mathrm{ml}$ and $0.100 \mathrm{mg} / \mathrm{ml}$. The total sugars were obtained by the following formula:

$$
Q=\frac{D . o_{\text {in }}}{0,0072} \times 10^{-3} \times 160
$$

Where $\mathrm{Q}=$ amount of sugar in the sample in $\mathrm{g} / 100 \mathrm{~g}$

D.o.in = optical density of the unknown (sample)

$0.0072=$ const ant

\section{Results}

3.1 Respondents characteristics and health personnel consulted
Table 1 shows the age, sex and other personal information of the respondents and the health staff consulted. Results of the study revealed that $30.5 \%$ of respondents belonged to the age group 50-59 years, this was followed by the age group of 70-79 years $(23.7 \%)$. The mean age of the studied respondents was 51.2 years. Among the selected respondents $59.9 \%$ of the respondents were female while rests were the male. Only $61 \%$ of the respondents had consulted with doctors.

\subsection{Prescribed and consumed vegetables}

All the consumed and prescribed vegetables were enlisted. Results presented in table 2 show the actual status of the vegetables prescribed to respondents and its actual consumption.

It is very clear from this table that the most consumed vegetable was $M$. esculenta leaves $(84.8 \%)$ and it was followed by $A$. hybridis (55.9\%) and I. batatas leaves $(41,1 \%)$. Results of this table also suggested that S. oleracea $(44.1 \%)$ and $H$. acetosella $(40.7 \%)$ were the vegetables which were prescribed to the diabetic but not frequently eaten by the patient. Furthermore C. esculenta (79.7\%), A. esculentus and C. pepo $(74.6 \%)$ vegetables were less prescribed but more eaten by the diabetics. Table 3 shows the frequency of vegetables consumption by diabetics. Result of this table shows that $41.1 \%$ of respondents use recommended vegetables at least once in a day while $30.5 \%$ respondents consumed vegetables twice in a day.

\subsection{Fiber and sugar contents of the selected vegetables}

Fiber and sugar contents of the selected vegetables are presented in Table 4. Fiber content of the analyzed vegetables ranged from $1 \mathrm{~g} / 100 \mathrm{~g}$ (B. oleracea \& S. nigrum) to $3.6 \mathrm{~g} / 100$ $\mathrm{g}$ (A. hybridis) while the sugar content ranged from $2.5 \mathrm{~g} / 100 \mathrm{~g}$ (A. esculentus) to $15.5 \mathrm{~g} / 100 \mathrm{~g}$ (M. esculenta).

Table I Age and sex of the patient and health personnel consulted $(\mathrm{N}=59)$.

\begin{tabular}{|c|c|c|c|}
\hline Characteristics & $\mathbf{F}_{0}$ & $\%$ & P-val \\
\hline \multicolumn{4}{|l|}{ Age Group (years) } \\
\hline $30-39$ & 11 & 18.6 & \\
\hline $40-49$ & 8 & 13.6 & \\
\hline $50-59$ & 18 & 30.5 & \\
\hline $60-69$ & 8 & 13.6 & \\
\hline $70-79$ & 14 & 23.7 & \\
\hline \multicolumn{4}{|l|}{ Sex } \\
\hline Male & 26 & 44.1 & $<0.001 *$ \\
\hline Female & 33 & 59.9 & \\
\hline \multicolumn{4}{|c|}{ Health staff consulted } \\
\hline Nurse & 16 & 27,1 & $<0.001 *$ \\
\hline Doctor & 36 & 61 & \\
\hline Nutritionist & 7 & 11,9 & \\
\hline
\end{tabular}

* Chi-square test single sample; $\mathrm{F}_{\mathrm{o}}=$ num ber of patients 
Table 2 Prescribed vegetables and vegetables actually consumed by respondents.

\begin{tabular}{|c|c|c|c|c|c|}
\hline Vegetables & & Not Prescribed & Prescribed \& consumed & not consumed & P-val \\
\hline Scientific and Vernacular Names & $\mathrm{N}$ & $\mathrm{F}_{\mathrm{o}}$ & $\mathrm{F}_{\mathrm{o}}$ & $\mathrm{F}_{\mathrm{o}}$ & \\
\hline Abelmoschus esculentus (Dongo dongo) & 59 & $44(74.6)^{* *}$ & $3(5.1)$ & $12(18.6)$ & $<0.001^{*}$ \\
\hline Amaranthus hybridis (Amaranth) & 59 & $4(6.8)$ & $33(55.9)$ & $22(37.3)$ & $<0.001 *$ \\
\hline Bracica oleracea (Cabbage), & 59 & $28(47.5)$ & $11(18.6)$ & $20(33.9)$ & $0.025^{*}$ \\
\hline Colocasia esculenta (Taro leaves), & 59 & $47(79.7)$ & $3(5.1)$ & $9(15.3)$ & $<0.001 *$ \\
\hline Cucurbita pepo (Pumpkin sheets), & 59 & $44(74.6)$ & $6(10.2)$ & $9(15.3)$ & $<0.001 *$ \\
\hline Gnetum africanum (Fumbwa) & 59 & $28(47.5)$ & $14(23.7)$ & $17(28.8)$ & $0.063^{*}$ \\
\hline Hibiscus acetosella (Sorrel of Guinea) & 59 & $18(30.5)$ & $17(28.8)$ & $24(40.7)$ & $0.482 *$ \\
\hline Ipomoea batatas (Sweet potato leaves) & 59 & $8(13.6)$ & $26(41.1)$ & $25(42.4)$ & $0.005^{*}$ \\
\hline Manihot esculenta (Cassava leaves) & 59 & $6(10.1)$ & $50(84.8)$ & $3(5.1)$ & $<0.001 *$ \\
\hline Solanum nigrum (Morelle, bilolo) & 59 & $33(55.9)$ & $17(28.8)$ & $9(15.3)$ & $0.001^{*}$ \\
\hline Spinaccia oleracea (spinach) & 59 & $15(25.4)$ & $18(30.5)$ & $26(44.1)$ & $0.193^{*}$ \\
\hline
\end{tabular}

* Chi-square test single semple $; \mathrm{F}_{\mathrm{o}}=$ num ber of patients concerned for this vegetable; $* *$ Numbers in parenthesis represent percentage

Table 3 Status of the daily consumption frequency of recommended vegetables.

\begin{tabular}{|lllc|}
\hline freque $n$ cy & $\mathbf{F}_{0}$ & $\%$ & P-val \\
\hline Once in a day & 26 & 44.1 & $0.193^{*}$ \\
\hline Twice in a day & 18 & 30.5 & \\
\hline Thrice in a day & 15 & 25.4 \\
\hline
\end{tabular}

* Chi-square test single sample $\mathrm{F}_{\mathrm{o}}=$ number of patients

Table 4 Fibers and sugar contents of analyzed vegetables.

\begin{tabular}{|lcc|}
\hline Analyze d vegetable & Fibers g/100g & Sugar g/100g \\
\hline Abelmoschus esculentus & 1.7 & 2.5 \\
\hline Amaranthus hybridis & 3.6 & 9.7 \\
\hline Bracica oleracea & 1.0 & 7.8 \\
\hline Colocasia esculenta & 2.1 & 7.6 \\
\hline Cucurbita pepo & 1.5 & 10.0 \\
\hline Gnetum africanum & 2.9 & 2.7 \\
\hline Hibiscus acetosella & 1.3 & 7.4 \\
\hline Ipomoea batatas & 1.9 & 13.3 \\
\hline Manihot esculenta & 1.7 & 15.6 \\
\hline Solanum nigrum & 1.0 & 6.8 \\
\hline Spinaccia oleracea & 1.29 & 4.7 \\
\hline
\end{tabular}

\section{Discussions}

More and less consumption of the vegetables can be justified by the food habits of the patients as well as the availability of same vegetables. The non prescription of vegetables like $C$. esculenta $(79.7 \%)$, A. esculentus and C. pepo $(74.6 \%)$ may be due to the scarcity of these products in the market or may be the limited knowledge of the prescriber on the vegetable. Only $41.1 \%$ of respondents used vegetables at least once in a day while $30.5 \%$ consumed twice. According to Ramon (2009) consumption of vegetables up to five servings and fruit a day is quite useful to overcome the diabetes. Some studies on the increase of the consumption of fruits and vegetables by diabetics 2 ( $\geq 6$ servings / day) showed an increase in the carotenoids content and enzymes associated with antioxidant properties of HDL (Daniels et al., 2014) and a decrease in glycosylated hemoglobin (HbA (1c) (Jenkins et al., 2011). A good nutritional profile (more fruits and vegetables, less meat, legumes and white bread) has favorable effects on plasma biomarkers associated with greater protection of type 2 diabetes (Heidemann et al., 2005).

The low frequency of consumption of vegetables by respondents associated with the effects of cooking expose the patient to deficiencies in some nutrients essential for the prevention of diabetes complications (vitamins and phytochemicals, pro-vitamin carotenoids A). Greater consumption of fruits and vegetables is recommended to cover 
the needs in pro-vitamin A carotenoids (Marie Jo Amiot Carlin et al., 2007). The most effective as a free radical scavenger is lycopene, followed by $\alpha$-carotene, $\beta$-cryptoxanthin, zeaxanthin and $\beta$-carotene, lutein. Carotenoids definitely have a complementary role or act synergistically with other antioxidants such as vitamins $\mathrm{C}$ and $\mathrm{E}$. It appears that green leafy vegetables are among the foods with the highest carotenoids content, watercress being the richest. Indeed, it is, with the parsley and spinach, a major source of $\beta$-carotene and lutein. Tomato and its derivatives are important sources of lycopene. The vegetarian diet has been shown effective in cardiovascular disease management, weight problem, and diabetes (Barnard et al., 2009).

Analyzed vegetables showed 1 - $3.6 \mathrm{~g} / 100 \mathrm{~g}$ fibers and $2.5 \mathrm{~g}$ $15.5 \mathrm{~g} / 100 \mathrm{~g}$ sugar contents and these contents are almost similar to the findings of Tandu (2001). Slight difference was reported between the results of present study and Tandu (2001) for some vegetables and could be explained by the difference in environmental conditions, difference in the sample processing.

Fiber increases satiety (Mello \& Laaksonen 2009) and slows down the digestive absorption of sugars and improves the glycemic index. Thus the presence of fibers plays an important role in reducing the glycemic index (Ford \& Mokdad 2001). As in diabetics, sugar consumption should take into account its glycemic index, so it is important to involve a fiber rich vegetable in daily menu to cover the minimum daily intake of $25 \mathrm{~g}$ (Mello \& Laaksonen 2009) or 15to $28 \mathrm{~g}$ of fiber per 1000 kcal (De Natale et al., 2009). Vegetables such as A. hybridis, $G$. africanum, C. esculenta, C. pepo, A. esculentus and $S$. oleracea would be more recommended.

Contrarily vegetables such as $M$. esculenta, I. batatas and $B$. oleraceae should be consumed moderately by diabetics because their fiber content is not so high to cover the total sugars in a meal although they contain other essential nutrients. In the intervention study involving fiber supplementation in type 2 diabetes, it has been proved that this diet reduces fasting blood glucose and HbA1c (Kaczmarczyk et al., 2012), and the minimum recommended intake of fiber was based on consumption of fruits and vegetables.

\section{Conclusion}

This study allowed us to identify some leafy vegetables rich in dietary fiber, consumption of which is beneficial for the diabetic but is not consumed. Vegetables such as A. hybridiss, G. africanum, C. esculenta, C. pepo, A. esculentus and $S$. oleracea should be more consumed. On the contrary vegetables such as $M$. esculenta, I. batatas and B. oleraceae should be eaten with moderation due to their sugar content compared to their fiber content, given that they are accompaniment foods that should bring much fiber of the daily ration.

\section{Conflict of interest}

Authors would hereby like to declare that there is no conflict of interests that could possibly arise.

\section{References}

AOAC (1990). Official methods of analysis, $14^{\text {th }}$ edition, Association of Official Analytical Chemists, Washington DC. Arlington, Virginia, USA.

Barnard ND, Gloede L, Cohen J, Jenkins DJ, TurnerMcGrievy G, Green AA, Ferdowsian H (2009) A low-fat vegan diet elicits greater macronutrient changes, but is comparable in adherence and acceptability, compared with a more conventional diabetes diet among individuals with type 2 diabetes. Journal of the American Dietetic Association 109:263-272. doi: http://dx.doi.org/10.1016/j.jada.2008.10.049

Boeing H, Bechthold A, Bub A, Ellin ger S, Haller D, Kroke A, Leschik-Bonnet E, Müller MJ, Oberritter H, Schulze M, Stehle P, Watzl B (2012) Critical review: vegetables and fruit in the prevention of chronic diseases. European Journal of Nutrition 51: 637-663. doi: 10.1007/s00394-012-0380-y.

Daniels JA, Mulligan C, McCance D, Woodside JV, Patterson C, Young IS, McEneny J (2014) A randomised controlled trial of increasing fruit and vegetable intake and how this influences the carotenoid concentration and activities of PON-1 and LCAT in HDL from subjects with type 2 diabetes. Cardiovascular Diabetology 13: 16. doi: 10.1186/1475-284013-16.

De Natale C, Annuzzi G, Bozzetto L, Mazzarella R, Costabile G, Ciano O, Riccardi G, Rivellese AA (2009) Effects of a plant-based high-carbohydrate/high-fiber diet versus highmonounsaturated fat/low-carbohydrate diet on postprandial lipids in type 2 diabetic patients. Diabetes Care 32:2168-73. doi: $10.2337 / \mathrm{dc} 09-0266$.

DuBois M, Gilles KA, Hamilton JK, Rebers PA, Smith F (1956) Colorimetric Method for Determination of Sugars and Related Substances. Analytical Chemistry 28 : 350-356. doi: 10.1021/ac60111a017.

Ford ES, Mokdad AH (2001) Fruit and vegetable consumption and diabetes mellitus incidence among U.S. adults. Preventive Medicine 32:33-39. doi:10.1006/pmed.2000.0772.

Gilbert ER, Liu D (2013) Anti-diabetic functions of soy isoflavone genistein: mechanisms underlying effects on pancreatic $\beta$-cell function. Food \& Function 4: 200-212. doi: 10.1039/C2FO30199G.

Gurukar MS, Mahadevamma S, Chilkunda ND (2013) Renoprotective effect of Coccinia indica fruits and leaves in experimentally induced diabetic rats. Journal of Medicinal Food 16:839-846. doi: 10.1089/jmf.2012.2689. 
Heidemann C, Hoffmann K, Spranger J, Klipstein-Grobusch K, Möhlig M, Pfeiffer AF, Boeing H (2005)A dietary pattern protective against type 2 diabetes in the European Prospective Investigation into Cancer and Nutrition (EPIC)--Potsdam Study cohort. Diabetologia 48:1126-1134. doi 10.1007/s00125-005-1743-1.

Isao M, Fumiaki I, Manson JoAnn E, Hu Frank B, Willett Walter C, van Dam Rob M, Sun Q (2013) Fruit consumption and risk of type 2 diabetes: results from three prospective longitudinal cohort studies. BMJ 2013; 347 :f5001. doi: http://dx.doi.org/10.1136/bmj.f5001.

Jenkins DJ, Srichaikul K, Kendall CW, Sievenpiper JL, Abdulnour S, Mirrahimi A, Meneses C, Nishi S, He X, Lee S, So YT, Esfahani A, Mitchell S, Parker TL, Vidgen E, Josse RG, Leiter LA (2011) The relation of low glycaemic index fruit consumption to glycaemic control and risk factors for coronary heart disease in type 2 diabetes. Diabetologia 54:271279. doi: 10.1007/s00125-010-1927-1.

Kaczmarczyk MM, Miller MJ, Freund GG (2012) The health benefits of dietary fiber: beyond the usual suspects of type 2 diabetes mellitus, cardiovascular disease and colon cancer. Metabolism Clinical and Experimental 61:1058-1066. doi: 10.1016/j.metabol.2012.01.017.

Kobayashi Y, Hattori M, Wada S, Iwase H, Kadono M, Tatsumi H, Kuwahata M, Fukui M, Hase ga wa G, Nakamura N, Kido Y (2013) Assessment of Daily Food and Nutrient Intake in Japanese Type 2 Diabetes Mellitus Patients Using Dietary Reference Intakes. Nutrients 5: 2276-2288. doi: $10.3390 /$ nu5072276.

Marie Jo Amiot Carlin, Pascale Barberger-Gateau, Jean Dallongeville, Luc Dauchet, Cécile Delcourt, Christian
Demigné, Christophe Dupont, Paule Latino-Martel, Claudie Roy, Philippe Verge (2007) Consommation de fruits et légumes et santé - Agores, www.agores.asso.fr/../FRUITS-ETLEGUMES / escofetl-chapitre1- ok.pdf consulté le 24/06/2014

Mello VD, Laaksonen DE (2009) Dietary fibers: current trends and health benefits in the metabolic syndrome and type 2 diabetes. Arquivos Brasileiros de Endocrinologia \& Metabologia 53: 509-518. http://dx.doi.org/10.1590/S000427302009000500004 .

Ramon C (2009) Diabète, Traitement Scientifique et naturel, éd. Vidasana $\mathrm{Pp} 142$.

Savini I, Catani MV, Evangelista D, Gasperi V, Avigliano L (2013) Obesity-Associated Oxidative Stress: Strategies Finalized to Improve Redox State. International Journal of Molecular Sciences 14:10497-10538. doi:10.3390/ijms140510497.

Tabesh M, Hariri M, Askari G, Ghiasvand R, Tabesh M, Heydari A, Darvishi L, Khorvash F (2013) The Relationship Between Vegetables and Fruits Intake and Glycosylated Hemoglobin Values, Lipids Profiles and Nitrogen Status in Type II Inactive Diabetic Patients. International Journal of Preventive Medicine 4(Suppl 1): S63-S67.

Tandu U (2001) Nutrition de la théorie à la pratique, presse de l’Université de Kinshasa Pp276.

Tol A, Sharifirad G, Shojaezadeh D, Tavasoli E, Azadbakht L (2013) Socio-economic factors and diabetes consequences among patients with type 2 diabetes. Journal of Education and Health Promotion 2: 12. doi: 10.4103/2277-9531.108009. 